\title{
Molt-inhibiting hormone stimulates vitellogenesis at advanced ovarian developmental stages in the female blue crab, Callinectes sapidus I: an ovarian stage dependent involvement Nilli Zmora, John Trant, Yonathan Zohar and J Sook Chung*
}

Address: Center of Marine Biotechnology, University of Maryland Biotechnology Institute, 701 E. Pratt St. Columbus Center Suite 236, Baltimore, MD 21202, USA

Email: Nilli Zmora - zmora@umbi.umd.edu; John Trant - trant@umbi.umd.edu; Yonathan Zohar - zohar@umbi.umd.edu; J Sook Chung* - chung@comb.umbi.umd.edu

* Corresponding author

Published: 7 July 2009

Saline Systems 2009, 5:7 doi:10.1 186/1746-1448-5-7
Received: 9 March 2009

Accepted: 7 July 2009

This article is available from: http://www.salinesystems.org/content/5/I/7

(C) 2009 Zmora et al; licensee BioMed Central Ltd.

This is an Open Access article distributed under the terms of the Creative Commons Attribution License (http://creativecommons.org/licenses/by/2.0), which permits unrestricted use, distribution, and reproduction in any medium, provided the original work is properly cited.

\begin{abstract}
To understand the hormonal coordination of the antagonism between molting and reproduction in crustaceans, the terminally anecdysial mature female Callinectes sapidus was used as a model. The regulatory roles of crustacean hyperglycemic hormone $(\mathrm{CHH})$ and molt-inhibiting hormone $(\mathrm{MIH})$ in vitellogenesis were examined. A competitive specific RIA was used to measure the levels of MIH and $\mathrm{CHH}$ in the hemolymphs of mature females at pre- and mid- vitellogenic stages, and their effects on vitellogenesis at early (early 2, E2) and mid vitellogenesis (3) stages were determined in vitro. A hepatopancreas fragments incubation system was developed and the levels of vitellogenin $(\mathrm{VtG})$, as well as $V t G$ mRNA and heterogeneous nuclear ( $h n) V t G$ RNA were determined using RIA or QPCR, respectively. MIH titers were four times higher at mid-vitellogenesis than at previtellogenesis, while $\mathrm{CHH}$ levels in the hemolymph were constant. In the in vitro incubation experiments, MIH increased both $V t G$ mRNA levels and secretion at ovarian stage 3. At stage E2, however, MIH resulted in a mixed response: downregulation of $V t G$ mRNA and upregulation of $h n V t G$ RNA. CHH had no effect on any of the parameters. Actinomycin D blocked the stimulatory effects of MIH in stage 3 animals on $V t G$ mRNA and $V t G$, while cycloheximide attenuated only $\mathrm{VtG}$ levels, confirming the MIH stimulatory effect at this stage. MIH is a key endocrine regulator in the coordination of molting and reproduction in the mature female $C$. sapidus, which simultaneously inhibits molt and stimulates vitellogenesis.
\end{abstract}

\section{Background}

It has been proposed in decapod crustaceans that the high energy demanding processes of molting and reproduction are mutually antagonistic and do not occur simultaneously [1]. The antagonism is clearly demonstrated in the female Callinectes sapidus: molting and reproduction occur in two distinctive life phases with molting cycles occurring only in the juvenile phase and ovarian development and spawning cycles occurring only in adulthood.

Ovarian development is a major reproductive process, during which oocytes grow as a result of vitellogenin production and its accumulation in the form of yolk protein (vitellin) and other cytoplasmic egg proteins in the 
oocytes [2]. In C. sapidus, vitellogenesis occurs primarily in the hepatopancreas after terminal/pubertal molt and requires a relatively short duration of 8-12 weeks for completion [3].

The phenomenon of reproductive phase accompanied by terminal anecdysis (halt of molting cycles) is found in only a few decapod crustaceans, including Maja squinado, Libinia emarginata, and Chionoecetes bairdi [4-7]. Most of these anecdysial animals are characterized by a degenerated molting gland, the $\mathrm{Y}$-organ (YO), and the resulting low levels of molting hormones (ecdysteroids) in the hemolymph [8]. However, the adult C. sapidus female is distinguished from these animals by having non-degenerated YO's, which retain their normal size and their capability to bind and respond to molt-inhibiting hormone (MIH) by elevation of cyclic GMP (cGMP). Furthermore, eyestalk ablation (the removal of the source for $\mathrm{MIH}$ ) induces molting in adult C. sapidus females [9], indicating that the YO's also preserve their steroidogenic potential. Taken together, unlike other anecdysial crustacean species, molting cycle in the mature female C. sapidus is temporarily arrested at intermolt stage, in synchrony with the reproductive phase. Since to date the neuroendocrine mechanism underlying these antagonistic processes has not been examined in any crustacean species, the mature C. sapidus female with its distinctive separate molting and reproductive phases, serves as an excellent model species to address the issue.

Molting and reproduction are regulated by the eyestalk derived crustacean hyperglycemic hormone $(\mathrm{CHH})$ family $[10,11]$ including $\mathrm{CHH}, \mathrm{MIH}$, mandibular organinhibiting hormone $(\mathrm{MOIH})$ [12], and gonad/vitellogenesis-inhibiting hormone (G/VIH) $[13,14]$. These neuropeptides are synthesized in specific neurosecretory cells of the medullar terminalis X-organ $(\mathrm{XO})$, stored, and released from the sinus gland (SG) in the eyestalk ganglia (XOSG complex). The names of these neuropeptides usually refer to their primary functions or structural affiliation to either $\mathrm{CHH}$ or MIH subfamilies.

$\mathrm{CHH}$ and MIH exist in different combinations and number of isoforms depending on the species. Multiple isoforms are found in the XOSG of penaeids, crayfish, and lobsters [15], whereas in crab species only two isoforms of $\mathrm{CHH}$ and one of MIH are detected [16-19]. Moreover, $\mathrm{CHH}$ neuropeptides are characterized by pleiotropicity and are usually involved in the regulation of several physiological processes including molting, reproduction, osmoregulation, energy metabolism, and stress response [20].

Molting is controlled by $\mathrm{CHH}$ and MIH. High circulating levels of these neuropeptides suppress synthesis and secre- tion of ecdysteroids from the YO's by down-regulating protein synthesis $[21,22]$ which in turn leads to low titers of ecdysteroids in the hemolymph $[7,23-25]$. Reproduction on the other hand is regulated both negatively and positively by $\mathrm{CHH}$ family neuropeptides. The inhibition is exerted by VIH in the eyestalk ganglia $[14,26,27]$, and its presence has been described in a few lobster species [28-31], Litopenaeus vannamei [32], and the isopod Armadillidium vulgare [33]. Vitellogenesis-stimulating hormone (VSH), identified as an isoform of MIH in the sand shrimp, Metapenaeus ensis [34], positively regulates vitellogenesis. In addition to the XOSG, it is expressed in the ventral nerve cord, thoracic ganglia, and brain. This finding implies that a MIH like neuropeptide may be involved in the regulation of reproduction.

Considering the roles of $\mathrm{CHH}$ and $\mathrm{MIH}$ in molting and MIH isoform action as a VSH, we aimed to understand how the antagonism between molting and reproduction is hormonally coordinated in the terminally anecdysial female C. sapidus. Our earlier study showed that like other crab species, only one form of $\mathrm{MIH}$ is identified in the XOSG of C. sapidus [35] and MIH mRNA [36]. In addition, we found no evidence of a MIH, MIH-like neuropeptide(s) or its mRNA in the thoracic ganglia or brain of the adult female (unpublished data). We therefore hypothesized that XOSG derived $\mathrm{CHH}$ or MIH actively inhibit molting in the female C. sapidus, while allowing reproductive processes to take place. Specifically, we questioned if $\mathrm{MIH}$ or $\mathrm{CHH}$ have a role in the regulation of vitellogenesis of $C$. sapidus. To address these questions, we first determined the hemolymph circulating concentrations of MIH and $\mathrm{CHH}$ and their mRNA levels in the $\mathrm{XO}$ of mature female C. sapidus. We also carried out in vitro studies on hepatopancreas tissue fragments to identify the regulatory roles of MIH and $\mathrm{CHH}$ in vitellogenesis, specifically at the levels of $V t G$ mRNA, VtG protein and heterogeneous nuclear $(h n) V t G$ RNA. Measuring $h n V t G$ RNA provided an additional tool to examine transcription. We report that MIH has a regulatory role in vitellogenesis in the female C. sapidus, while $\mathrm{CHH}$ seems to have no clear involvement. Specifically, MIH upregulated $V t G$ mRNA, $h n V t G$ RNA and $\mathrm{VtG}$ secretion in heptopancreas fragments in vitro in the advanced vitellogenic stage. Interestingly, MIH downregulated $V t G$ mRNA, upregulated $h n V t G$ RNA and had no effect on VtG secretion in the early vitellogenic stage.

\section{Results \\ MIH and CHH titers in the hemolymph of reproductive females}

Neuropeptides in the hemolymph were determined by specific radioimmunoassay (RIA) in 10 females at ovarian stages 1 and 3, representing pre-vitellogenic and midvitellogenic stages, respectively. The results showed a significant four- fold increase in MIH levels at ovarian stage 
$3(19.6 \mathrm{fmol} / \mathrm{ml})$ compared to stage $1(5.7 \mathrm{fmol} / \mathrm{ml})$ (Fig. 1Aa). CHH levels did not differ between the stages and ranged between 130 and $150 \pm 49 \mathrm{fmol} / \mathrm{ml}$ which are 6 - 20 times higher than those of MIH (Fig. 1Ab). MIH and $\mathrm{CHH}$ mRNA levels in the XO of mature females at the same stages did not significantly differ and were 1500 2500 copies/20 ng total RNA for MIH and 15000-40000 copies/20 ng total RNA for $\mathrm{CHH}$ (Figs. $1 \mathrm{Ba}$ and $1 \mathrm{Bb}$ ). Accordingly, the concentrations of ecdysteroids in the hemolymph of these females were low at ovarian stages 1 and 3: 7 to $5 \mathrm{ng} / \mathrm{ml}$, respectively (not shown).

\section{In vitro incubation of hepatopancreas fragments}

The effects of sinus gland neuropeptides $(\mathrm{CHH}$ and $\mathrm{MIH})$ on $\mathrm{VtG}$ expression and secretion

To establish an in vitro bioassay, a preliminary experiment was conducted to determine the effect of incubation period on the stability of total RNA and $V t G$ mRNA as well as the optimal incubation time and dose of neuropeptides for hepatopancreas fragments in vitro. The stability of RNA was tested by visualization of the total RNA, determined by the integrity of $18 \mathrm{~S}$ and $28 \mathrm{~S}$ ribosomal(r) RNA subunits of the hepatopancreas extracted immediately after dissection ( $\mathrm{t}=0$ point) and after a $6 \mathrm{~h}$ incubation. The results presented in additional file 1 show that $18 \mathrm{~S}$ and $28 \mathrm{~S}$ rRNA bands remained stable and similar to that of $t$ $=0$ point after the $6 \mathrm{~h}$ incubation. The levels of $V t G$ mRNA were further tested by quantitative PCR (QPCR) analysis on hepatopancreas fragments incubated in plain media. Levels were found to be constant during the incubation period (Fig. 2A).

The effect of different doses of $\mathrm{CHH}$ or $\mathrm{MIH}$ on $\mathrm{VtG}$ mRNA was determined by incubating hepatopancreas fragments of stage (early 2) E2 animals for 1 or $6 \mathrm{~h}$. At $1 \mathrm{~h}$ incubation, $\mathrm{MIH}$ at $0.05,0.2$ and $2 \mathrm{nM}$ concentrations

A
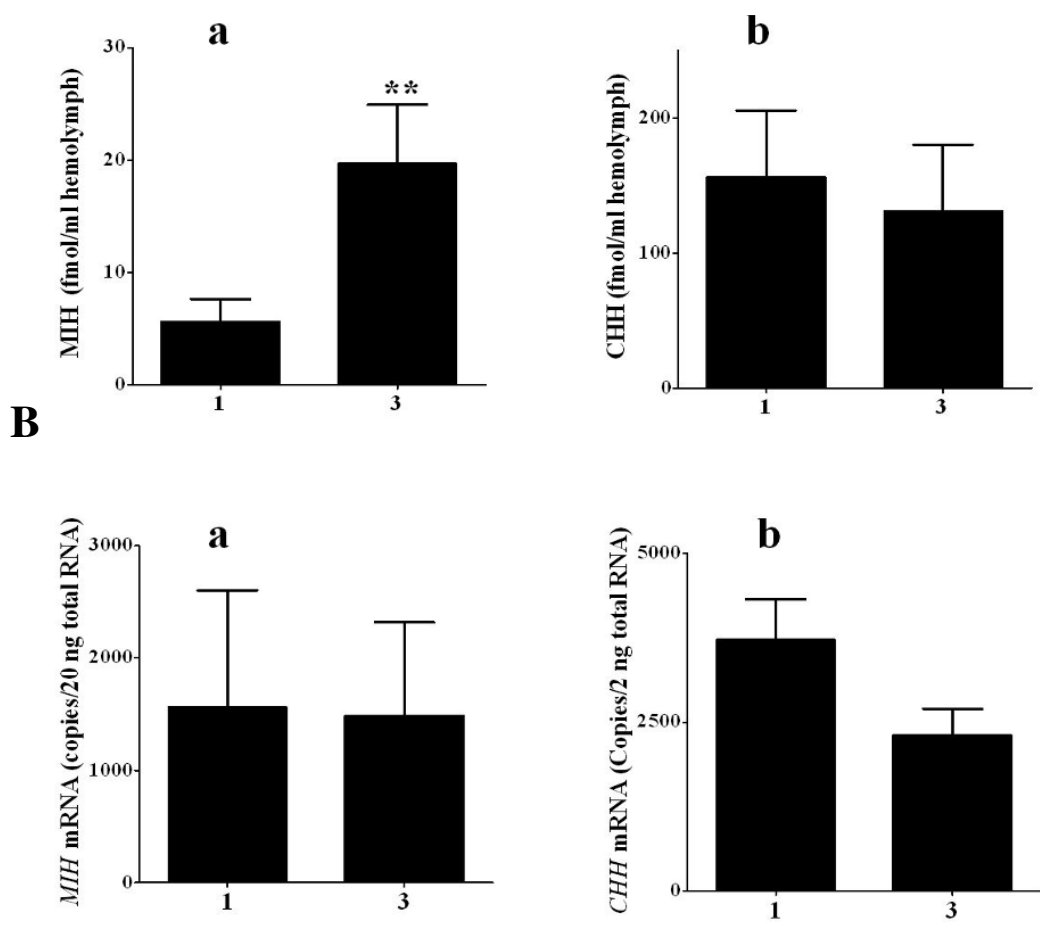

\section{Ovarian stage}

Figure I

MIH and $\mathrm{CHH}$ levels in the hemolymph and mRNAs in the XO of pre- and mid-vitellogenic females (ovarian stage I and 3). A) hemolymph titers and $\mathrm{B}$ ) mRNA a) $\mathrm{MIH}, \mathrm{b}) \mathrm{CHH}$. $\mathrm{MIH}$ and $\mathrm{CHH}$ neuropeptides in the hemolymph were extracted with $40 \%$ isopropanol for the extraction of $\mathrm{CHH}$ and $60 \%$ isopropanol for the extraction of $\mathrm{MIH}$ followed by a specific RIA in 10 females at each stage I or 3. MIH and CHH mRNA levels were determined using QPCR in I7 females at stage I and $2 \mathrm{I}$ females at stage 3 and are presented as copies/20 ng total RNA. Results are presented as mean $\pm S E M(N=I 0)$. $* *,=P$ $\leq 0.01$. 
A

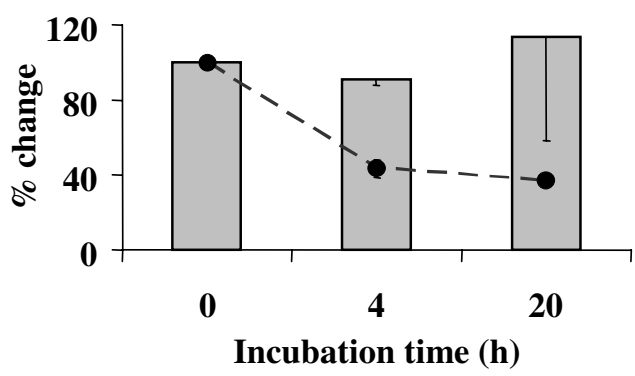

B
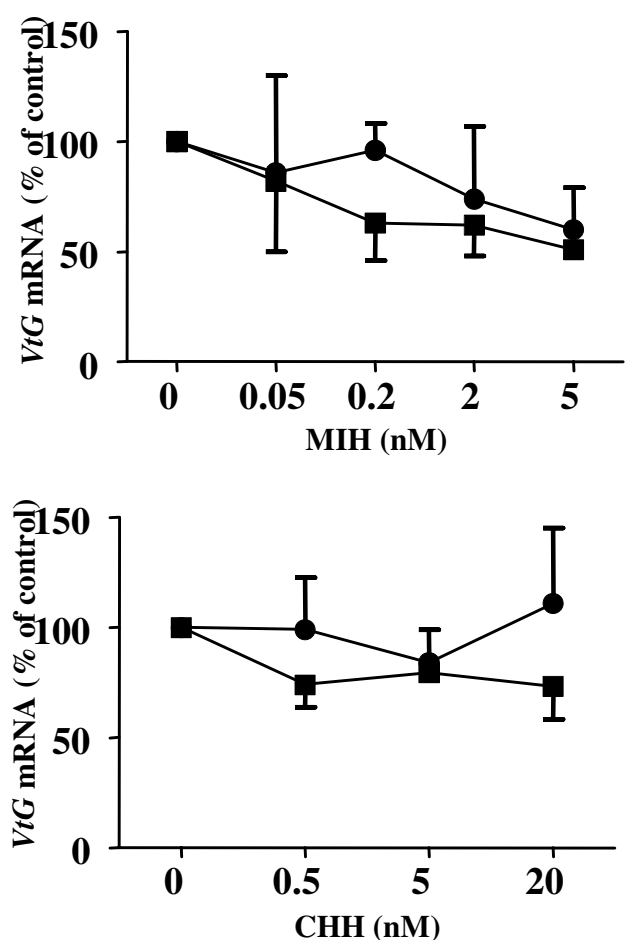

Figure 2

Evaluation and optimization of the hepatopancreas incubation experiment. A) Incubation period had no effect on the stability of $V t G$ mRNA in hepatopancreas fragments of females at early ovarian stage 2 (E2). Bars, normalized VtG mRNA; dashed line, total RNA. MIH had a more pronounced decreasing effect on $V t G$ mRNA levels than $\mathrm{CHH}(0-20 \mathrm{nM})$ in hepatopancreas fragments of females at E2 incubated for I and $6 \mathrm{~h}, \mathrm{~B}$ ) Incubation with 0 to $5 \mathrm{nM} \mathrm{MIH}$ and C) Incubation with 0 to $20 \mathrm{nM} \mathrm{CHH}$. circles, I h incubation; squares, $6 \mathrm{~h}$ incubation. Data are presented as mean \pm SEM $(N=3)$.

had no effect, however $5 \mathrm{nM}$ resulted in a non-statistically significant decrease of $25 \%$ of control in $V t G$ mRNA. During the $6 \mathrm{~h}$ incubation, the effect was more pronounced, although still statistically insignificant due to the low $\mathrm{N}$ number $(\mathrm{N}=3)$. MIH at $0.2,2$, and $5 \mathrm{nM}$ showed a trend of dose dependent effect, where $V t G$ mRNA levels dropped to $62 \%, 62 \%$, and $51 \%$ of the control, respec- tively (Fig. 2B). CHH at 0.5, 5, and $20 \mathrm{nM}$ showed no difference from control on $V t G$ mRNA levels at both 1 and 6 $\mathrm{h}$ incubation (Fig. 2C). Based on these results, the subsequent in vitro experiments were carried out at $6 \mathrm{~h}$ incubation, unless specified otherwise.

The effects of $\mathrm{CHH}$ and $\mathrm{MIH}$ on vitellogenesis were further examined on hepatopancreas of females at early and mid-vitellogenic stages (E2 and 3, respectively). $\mathrm{CHH}$ (20 $\mathrm{nM})$ significantly reduced $V t G$ mRNA levels by $20 \%(\mathrm{~N}=$ 21) of control at $\mathrm{E} 2$ and had no effect at stage $3(\mathrm{~N}=6)$ (Fig. 3Ab). MIH however, revealed a stage dependent response. $\mathrm{MIH}(2 \mathrm{nM})$ reduced $V t G$ mRNA levels in the hepatopancreas of females at E2 by $60 \%(\mathrm{~N}=21)$, but caused an increase at stage $3(\mathrm{~N}=6)$ (Fig. 3Aa). The effect of MIH on VtG secretion from hepatopancreas fragments was stage dependent: at E2, no change was detected $(\mathrm{N}=$ 6 ), while at stage 3, MIH increased the levels of $\mathrm{VtG}$ in the media to $204 \pm 34 \%$ over the control $(\mathrm{N}=5)$ (Fig. 3Ba). $\mathrm{CHH}$ had no significant effect on $\mathrm{VtG}$ secretion at $\mathrm{E} 2$ and 3 stages $(\mathrm{N}=5)$ (Fig. $3 \mathrm{Bb})$.

To clarify the results obtained for stage E2, the effect of $\mathrm{CHH}$ and MIH on VtG transcription was also tested on de novo synthesis of $V t G$ mRNA by measuring heterogeneous nuclear RNA of $V t G$ ( $h n V t G$ RNA). The levels of $h n V t G$ RNA increased to $270 \%$ over the control with $\mathrm{MIH}$, whereas $\mathrm{CHH}$ had no effect after a $1 \mathrm{~h}$ incubation. This effect disappeared at the $2 \mathrm{~h}$ incubation period $(\mathrm{N}=3)$ (Fig. 4A). Since a difference in $h n V t G$ RNA was only measurable at the $1 \mathrm{~h}$ but not $2 \mathrm{~h}$ incubation, experiments testing $h n V t G$ RNA were set for $1 \mathrm{~h}$. In a larger scale set of experiments with a $1 \mathrm{~h}$ incubation, MIH caused a $\sim 2.5$ fold increase $(256 \pm 86 \%)$ in $h n V t G$ RNA levels in the hepatopancreas of females at $\mathrm{E} 2$, while $\mathrm{CHH}$ had no effect $(\mathrm{N}=11)$ (Fig. 4B).

The effects of co-incubation of actinomycin $D$ and cycloheximide with $\mathrm{MIH}$ on $\mathrm{VtG}$ expression and $\mathrm{Vt} G$ production

To test whether the changes in VtG secretion by MIH is associated with its impact on $V t G$ mRNA, hepatopancreas fragments of females at ovarian stage 3 were co-incubated with $2 \mathrm{nM} \mathrm{MIH}$ and a transcription inhibitor (actinomycin D) or a translation inhibitor (cycloheximide). These inhibitors were tested at two different concentrations: 0.5 and $10 \mu \mathrm{M}$. MIH increased VtG levels by $51 \%$ compared to the control and $\mathrm{MIH}+0.1 \% \mathrm{v} / \mathrm{v}$ EtOH increased by $45 \%(\mathrm{~N}=5)$. Actinomycin $\mathrm{D}$ at 0.5 and $10 \mu \mathrm{M}$, in the presence of $\mathrm{MIH}$, reduced $\mathrm{VtG}$ levels to $60 \%$ and $49 \%$ of MIH treatment, respectively (Fig. 5A), which were similar to the media control. $\mathrm{MIH}+10 \mu \mathrm{M} \mathrm{AD}$ decreased $V t G$ mRNA to $51 \%$ of MIH treatment (Fig. 5B).

Cycloheximide at 0.5 and $10 \mu \mathrm{M}$ co-incubated with $\mathrm{MIH}$ (+ EtOH), reduced VtG levels to 35\% of MIH (+ EtOH) 
a

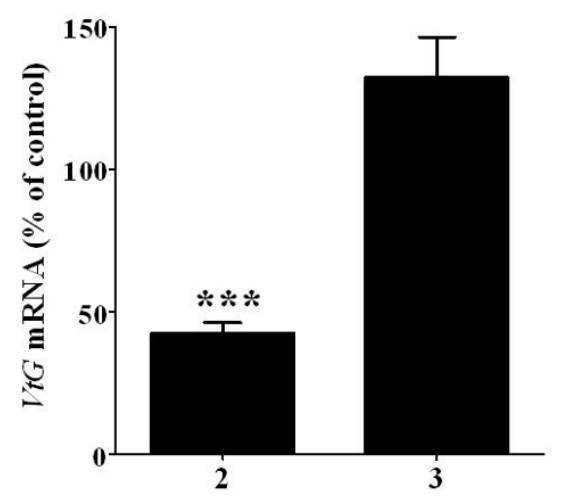

a

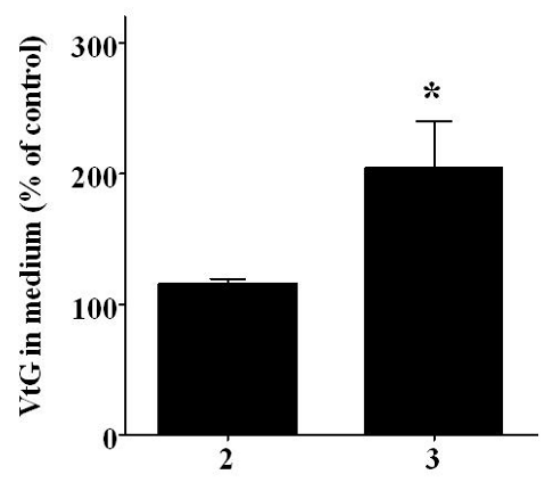

b

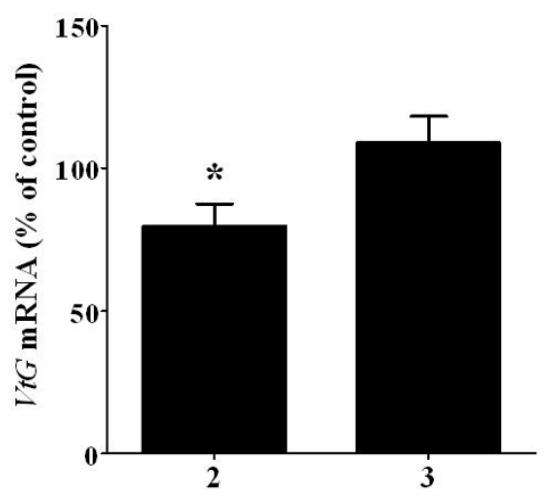

b

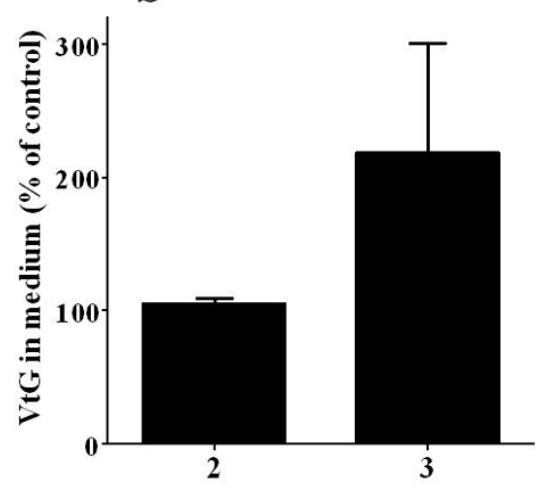

\section{Ovarian stage}

Figure 3

MIH stimulates VtG expression and secretion in hepatopancreas of females at ovarian stage 3 and downregulates VtG mRNA at stage early 2 (E2) while CHH shows no significant effect. A) VtG mRNA and B) VtG in the medium. a) $2 \mathrm{nM}$ MIH treatment and b) $20 \mathrm{nM} \mathrm{CHH}$ treatment. The effects on $V t G$ mRNA and protein secretion were tested in females at $E 2(N=2 I$ and $N=6$, respectively) and stage $3(N=6$ and $N=5$, respectively). Results are presented as mean \pm SEM of $\%$ of control. $*=\mathrm{P} \leq 0.05 ; * * *=\mathrm{P} \leq 0.00 \mathrm{I}$.

and $\sim 54 \%$ of the media control, but had no effect on $V t G$ mRNA levels (Fig. 6A and 6B). HnVtG RNA was not measured in this particular set of experiments as a different experimental setup is required (i.e., $1 \mathrm{~h}$ incubation time, see Fig. 4A).

The effect of other sinus gland factors on $\mathrm{VtG} m$ mRNA levels The pooled HPLC fractions of sinus-glands (SG) from stage 3 vitellogenic females without $\mathrm{CHH}, \mathrm{MIH}$, and crustacean hyperglycemic hormone precursor related-peptide (CPRP) were tested using an in vitro hepatopancreas incubation to determine whether other sinus gland-derived substances had an effect on $V t G$ expression. No effect was found with $5 \%$ and $25 \%$ of SG equivalent (minus $\mathrm{CHH}$, $\mathrm{MIH}$, and CPRP) on $V t G$ expression in the hepatopancreas fragments (Fig. 7). CPRP was also tested, as it is one of the three major neuropeptides in the SG. CPRP fraction at 5\% and 25\% SG equivalents and purified native CPRP at 25 $\mathrm{nM}$ showed no significant effect on $V t G$ expression (Fig. 7).

\section{Discussion}

The present study aimed to gain a better understanding of how XOSG derived neuropeptides regulate the antagonism between vitellogenesis and molting in the terminally anecdysial mature female $C$. sapidus. We determined the titers of $\mathrm{CHH}$ and $\mathrm{MIH}$ in the hemolymph of mature females at different vitellogenic stages and tested their effect on vitellogenesis, in vitro. Hemolymph titers of $\mathrm{CHH}$ in these females were comparable to those measured in juvenile animals [35] and remained unchanged at ovarian stages 1 and 3. However, the detection of MIH in 
$\mathbf{A}$

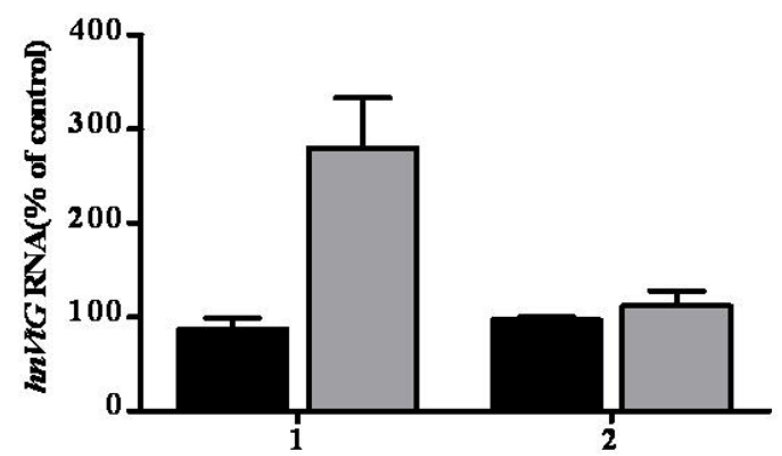

B

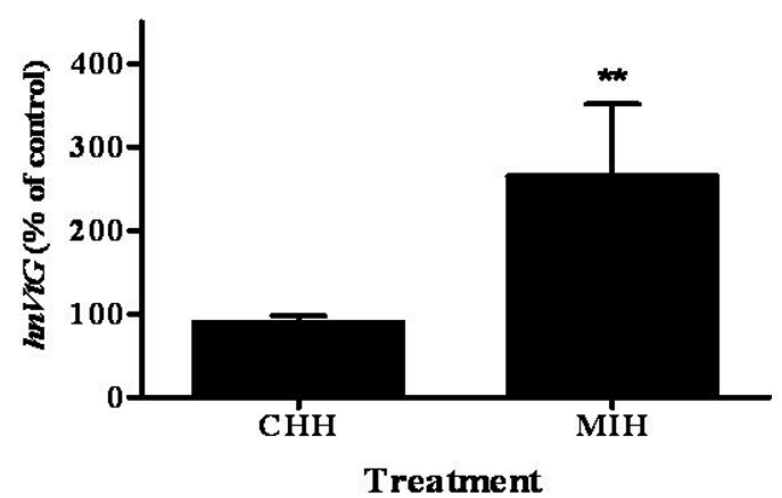

Figure 4

MIH upregulates hnVtG RNA in hepatopancreas of females at ovarian stage E2 after I $h$ incubation. A) Changes in $h n V t G$ RNA were measured after $\mathrm{I} h$ or $2 \mathrm{~h}$ incubation with either $20 \mathrm{nM} \mathrm{CHH}$ (black bars) or $2 \mathrm{nM} \mathrm{MIH}$ (grey bars) and are measurable only at I h incubation period $(\mathrm{N}=3)$. B) $h n V t G$ RNA change in response to $20 \mathrm{nM} \mathrm{CHH}$ or $2 \mathrm{nM} \mathrm{MIH}(\mathrm{N}=\mathrm{II})$. Results are presented as mean $\pm \mathrm{SEM}$ of $\%$ of control. $*=\mathrm{P} \leq 0.05 ; * *=\mathrm{P} \leq 0.0 \mathrm{l}$.

the hemolymph of mature females was initially surprising considering they ceased molt. Hemolymph MIH levels at mid-vitellogenic ovarian stage 3 were four times higher than those of stage 1 (Fig. 1A), implying a putative role for $\mathrm{MIH}$ in vitellogenesis. $\mathrm{MIH}$ and $\mathrm{CHH}$ mRNA levels were statistically indifferent in both ovarian stages, with $\mathrm{MIH}$ exhibiting high variation within each group (Fig. 1B). These results indicate that the expression level of these neuropeptides is not correlated with their secretion from the SG, as shown in other studies [22,36].

The in vitro hepatopancreas fragments incubation system was used to further determine whether circulating $\mathrm{CHH}$ and MIH play a regulatory role in vitellogenesis in C. sapidus $[5,27,28,32,34,37,38]$. Their effect was tested at the levels of $\mathrm{VtG}$ gene transcription by measuring changes in
$\mathbf{A}$

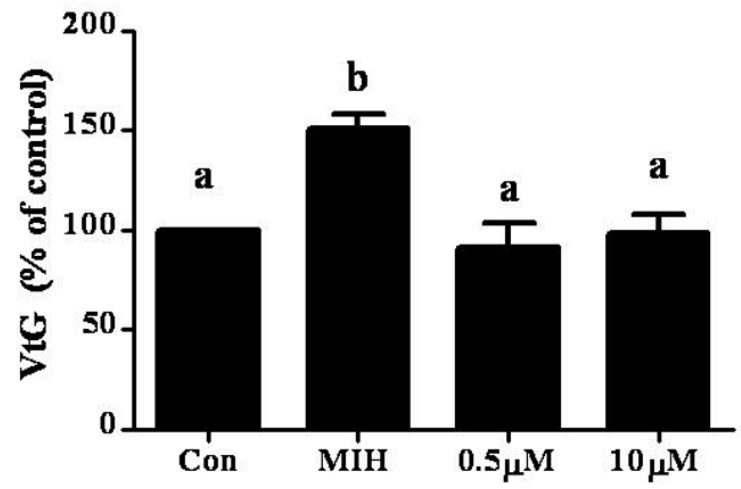

B

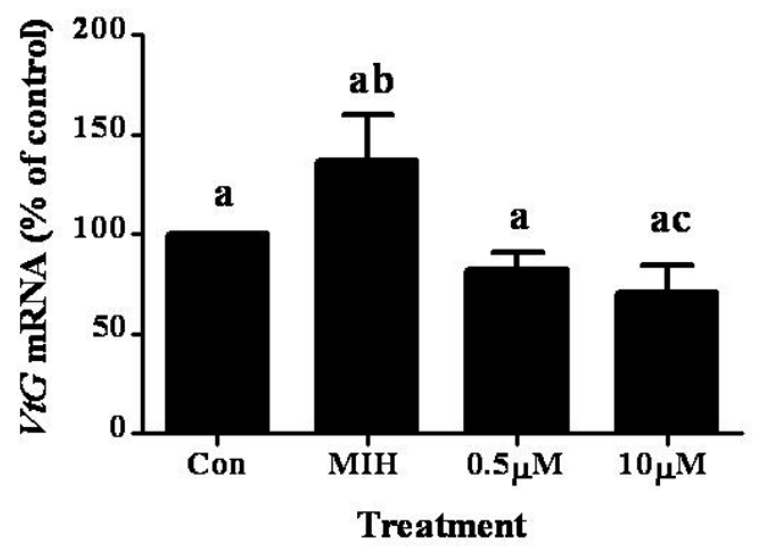

Figure 5

Co-incubation of MIH and actinomycin D (AD) blocks the increase of $\mathrm{VtG}$ protein $(\mathrm{A})$ and $\mathrm{VtG}$ mRNA (B) in hepatopancreas fragments of ovarian stage 3 females. The concentration of $\mathrm{MIH}$ was $2 \mathrm{nM}$ and those of actinomycin D were 0.5 and $10 \mu \mathrm{M}$. Results are presented as mean \pm SEM of $\%$ of control $(N=5)$. The alphabetical letters show the significant differences at $P<0.05$.

$V t G$ mRNA levels, and VtG translation, determined by changes in VtG secretion as this protein does not accumulate in the hepatopancreas but is being secreted immediately following translation [3]. $\mathrm{CHH}$ had no consistent effects on vitellogenesis: it decreased $V t G$ mRNA by $20 \%$ only at stage E2 and had no effect on $\mathrm{VtG}$ secretion at both E2 and 3 stages (Figs. 3Ab and 3Bb). However, with $\mathrm{MIH}$ treatment, both $V t G$ mRNA and VtG protein levels exhibited different responses at the two ovarian stages tested. While $V t G$ mRNA decreased at stage E2, it slightly increased at stage 3 in response to $\mathrm{MIH}$ (Fig. 3Aa). VtG secretion did not differ from control treatment at stage E2 but increased at stage 3 (Fig. 3Ba). These results imply that MIH may have an inhibitory role at early ovarian stages, 

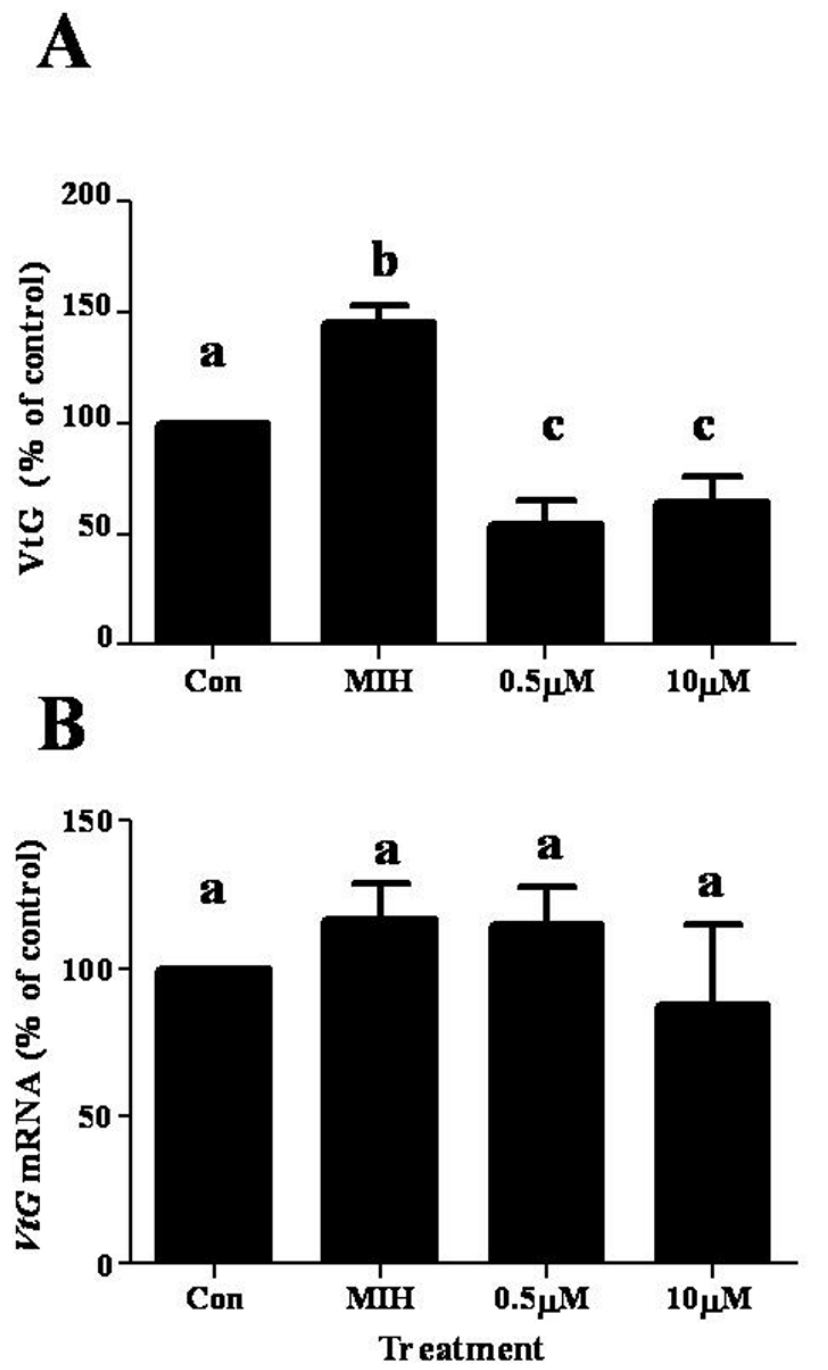

Figure 6

Co-incubation of MIH and cycloheximide reversed the effect of MIH on VtG protein (A) and had no effect on VtG mRNA (B). The concentration of MIH was 2 $\mathrm{nM}$ and those of cycloheximide were 0.5 and $10 \mu \mathrm{M}$. Results are presented as mean \pm SEM of $\%$ of control $(N=5)$. The alphabetical letters show the significant differences at $\mathrm{P}<$ 0.05 .

and a stimulatory role at mid ovarian stages. To determine whether MIH indeed downregulates $V t G$ gene transcription at stage E2, we further tested the activation of $V t G$ gene by measuring the short-lived $h n V t G$ (= pre $V t G$ mRNA). The increase of $h n V t G$ RNA levels in response to $\mathrm{MIH}$ at this stage indicated that the $V t G$ gene is activated and thus its transcription is being enhanced (Fig. 4). These results were corroborated by a different set of experiments in which incubation of hepatopancreas fragments with membrane permeable cyclic nucleotides at stage E2 resulted in the same response [39]. The reason for the contradicting response of $V t G m R N A$ and $h n V t G$ RNA is unclear and will require further study.

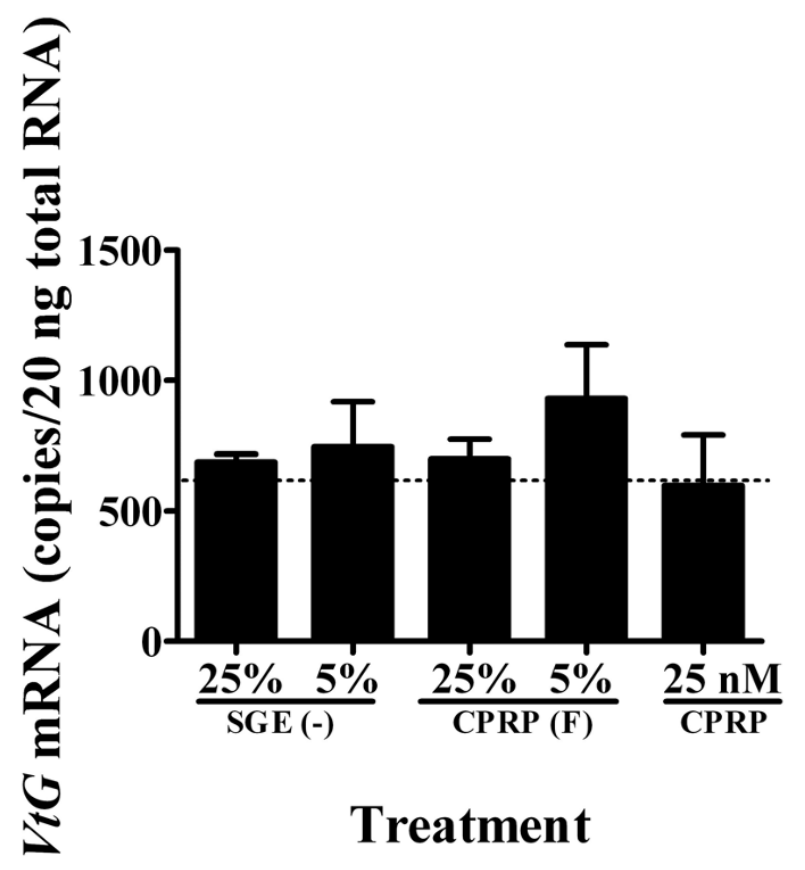

Figure 7

Sinus gland extract (SGE) without the known neuropeptides caused no change in VtG mRNA in hepatopancreas of stage 3 in vitro. Hepatopancreas fragments were incubated with sinus gland extract from which CPRP, $\mathrm{CHH}$, and $\mathrm{MIH}$ were removed (SGE(-)) at $25 \%$ and $5 \%$ sinus gland equivalent; CPRP HPLC fraction (CPRP F) at 25\% and $5 \%$ sinus gland equivalent; and at $25 \mathrm{nM}$ CPRP. Control level is indicated by a dashed line and data are presented as mean $\pm \operatorname{SEM}(\mathrm{N}=5)$.

Stimulation of vitellogenesis by SG-MIH has not been reported in decapod crustaceans, with the exception of MIH-B in M. ensis [34]. To verify the stimulatory effect of MIH on vitellogenesis at ovarian stage 3 , actinomycin D (a general inhibitor of eukaryotic transcription) and cycloheximide (a general inhibitor of eukaryotic translation), were separately co-incubated with MIH. The addition of actinomycin $\mathrm{D}$ and cycloheximide to $\mathrm{MIH}$ treatment resulted in a decrease to $60 \%$ and $35 \%$ of $\mathrm{VtG}$ levels, respectively, compared to MIH alone (equivalent to $95 \%$ and $54 \%$ of control levels) (Figs. 5 and 6). Actinomycin D co-incubated with MIH, decreased VtG mRNA levels by $49 \%$, indicating that the respective decrease in VtG levels is likely to be a result of the reduced $V t G$ transcription (Fig. 5A). The decrease of $V t G$ mRNA with MIH/actinomycin D to control levels suggests pre-existing $V t G$ mRNA in the hepatopancreas fragments. Furthermore, cycloheximide probably blocked the translation of the newly MIH induced $V t G$ mRNA as well as the pre-existing $V t G$ mRNA, resulting in lower levels of $\mathrm{VtG}$ protein compared to the control. In addition, the unchanged levels of $V t G$ mRNA with $\mathrm{MIH} /$ cycloheximide imply that the transcription 


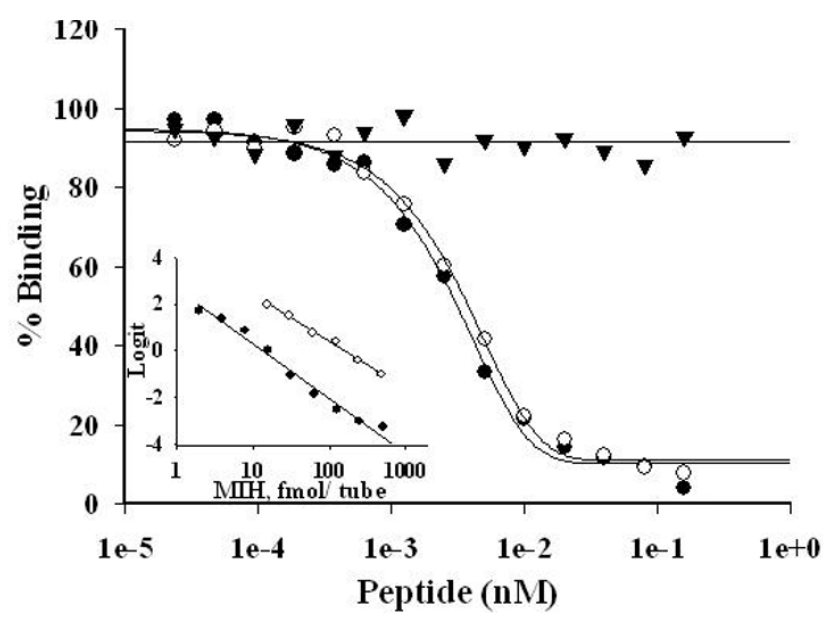

Figure 8

C. sapidus MIH antibody demonstrates high and equal specificity to MIH and $\mathrm{rMIH}$ and does not cross react with CHH. Standard curves of $\mathrm{MIH}, \mathrm{rMIH}$ and $\mathrm{CHH}$ with MIH antibody. Neuropeptides at concentrations ranging from $0.25 \mathrm{pM}$ to I nM were applied to RIA using anti-MIH raised against $\mathrm{rMIH}$ produced in Drosophila S2 cells at I:20,000 final dilution. Close circles- nMIH, open circles- rMIH, triangles$\mathrm{CHH}$. Inset- Parallelism of nMIH and diluted hemolymph tested by MIH RIA and shown in linear regressions. Close circles- nMIH, open circles- hemolymph.

machinery was not affected. Overall, these results demonstrate that MIH stimulation occurs at transcription and translation of $\mathrm{VtG}$ at ovarian stage 3.

Support evidence for MIH regulation in vitellogenesis is provided by the appearance of specific binding sites for $\mathrm{MIH}$ in the hepatopancreas of mature female C. sapidus. The abundance of the binding site increased gradually with ovarian development and was higher at stage 3 than at stages 1 and 2 [39].

It is tacitly accepted that $\mathrm{V} / \mathrm{GIH}$ inhibits vitellogenesis, while vitellogenin/gonad-stimulating hormone (V/GSH) enhances vitellogenesis processes. However, $\mathrm{CHHs}$ were shown to inhibit general mRNA synthesis in the ovaries of vitellogenic female Penaeus semisulcatus [40]. The few cases reporting the decrease of $V t G$ mRNA levels by $V / G I H$ and $\mathrm{CHH}$ have been shown in ovaries of immature penaeid females $[28,32,41]$. Although these studies were conducted on ovarian tissue and not hepatopancreas, they support our finding of decreased $V t G$ mRNA levels and indicate that this effect may be more common at early stages of ovarian development.

The observation that MIH positively regulates vitellogenesis at stage 3 is concordant with a previous report in which the non SG-MIH isoform stimulated vitellogenesis in the shrimp M. ensis [34]. The lack of MIH or MIH-like neu- ropeptide in non-XOSG tissues of the female C. sapidus, suggests that the vitellogenesis-stimulatory role is carried out by the SG-MIH. To our knowledge, the current study is the second description of the effect of MIH neuropeptide on $V t G$ mRNA in the hepatopancreas of a mature vitellogenic female crustacean.

In light of the mutual antagonism of molt and reproduction, the coordinated control of these two processes in crustacean species that continue to molt after puberty may require a complex regulatory system to allow both events [1]. The control may be exerted by multiple $\mathrm{CHH}$ and MIH isoforms, which indeed are found in non- crab species such as penaeids, crayfish, and lobsters [15]. It also can be controlled by pleiotropic neuropeptides in species carrying only a few neuropeptide forms, such as $C$. maenas $[17,18]$ and Necora (unpublished observation) that do molt during their adulthood. Low ecdysteroid circulating levels were also observed in another anecdysial crab, the C. opillio [42], suggesting that terminal anecdysis is associated with remarkably low ecdysteroids levels (lower than intermolt juveniles levels) in the hemolymph. Nevertheless, the two groups (terminally anecdysial or those that molt during their adulthood) may differ only in the duration of the intermolt stage, i.e., extended intermolt period in species like the female C. sapidus. Altogether, based on the low ecdysteroid level in the hemolymph compared to high $\mathrm{MIH}$ and $\mathrm{CHH}$ levels, and the potentially functional $\mathrm{YO}$, we conclude that the activity of the YO is suppressed by MIH in the mature female C. sapidus. Furthermore, our results suggest that the SG of adult female C. sapidus does not contain another vitellogenic regulatory factor(s) (Fig. 7).

\section{Conclusion}

The current study tested the possible regulatory roles of SG-MIH, CHH and CPRP in vitellogenesis, in vitro. The results show that $\mathrm{MIH}$ regulates vitellogenesis in a vitellogenic stage dependent manner: $\mathrm{MIH}$ is stimulatory at the levels of both transcription and translation of $\mathrm{VtG}$ at midvitellogenesis but its effect seems different at early stages. In light of the role of MIH in vitellogenesis, we infer that MIH may play a dual role in females of crab species that exhibit a terminal anecdysis upon sexual maturity in their life cycle: maintaining intermolt, while regulating vitellogenesis.

\section{Methods \\ Animals}

Female C. sapidus were captured in the Rhode River (a tributary of the Chesapeake Bay, USA) transported in aerated water, and held in recirculating 4.5 cubic meter tanks at environmental conditions matching the Bay for 2-5 days before dissection. Ovarian development was staged based on ovarian weight and gamete size according to criteria established previously [43]. Stage early 2 (E2) represents 
the beginning of vitellogenesis where oocyte size is small and similar to those at stage 1, but vitellin (yellow in color) starts to accumulate within the oocyte. This stage is the earliest point of detecting both $V t G$ mRNA and $\mathrm{VtG}$ protein [3].

\section{Batch purification and quantification of native $\mathrm{CHH}$, native $M I H$, and recombinant $M I H$}

Neuropeptides of sinus glands (SG) were purified using RP-HPLC as described [44]. Amino acid analyses were carried out for the quantification of the purified native $\mathrm{MIH}$, native $\mathrm{CHH}$, and recombinant $\mathrm{MIH}(\mathrm{rMIH})$ using the $o$ phthalaldehyde pre-column derivation method as described [16].

\section{$\mathrm{CHH}$ and MIH concentrations in the hemolymph}

Hemolymph samples were collected and frozen at $-20^{\circ} \mathrm{C}$ until processed. Neuropeptides were extracted from $1 \mathrm{ml}$ hemolymph by adding isopropanol to $40 \%(\mathrm{v} / \mathrm{v})$ for $\mathrm{CHH}$ extraction followed by centrifugation at $2000 \mathrm{rpm}$ for $30 \mathrm{~min}$ at $4^{\circ} \mathrm{C}$. The resulting pellet was re-extracted with $60 \%$ isopropanol (for MIH extraction) and pelleted as before. Supernatants were pooled and dried under vacuum (SpeedVac, Jouan) before being analyzed by RIAs as described [45]. The antiserum used in MIH RIA was generated in rabbits (Proteintech Group Inc.) against recombinant MIH with a His Tag at its $\mathrm{C}$ terminus, produced in an S2 Drosophila cell expression system. Both native [ $\left.{ }^{125} \mathrm{I}\right]$ MIH and [ $\left.{ }^{125} \mathrm{I}\right] \mathrm{CHH}$ were prepared using a chloramine-T labeling method. [125I] MIH or [125I] CHH was separated from free [125I] on a PD 10 column (GE Healthcare) as described [16]. Specific activities were approximately 300-500 Ci/mmol. A standard curve of MIH RIA ranging from $0.1-1000 \mathrm{fmol} /$ tube was prepared with native $\mathrm{MIH}$ and a final dilution of MIH antiserum at 1:20,000 (Fig. 8). The sensitivity of typical MIH RIAs was between $1.210^{-12}$ and $2.5 \times 10^{-11} \mathrm{M}$, with an $\mathrm{ED}_{50}$ value of $5.73 \pm 0.02 \times 10^{-}$ ${ }_{10} \mathrm{M}(\mathrm{N}=3)$ and the detection limit of $1.2 \times 10^{-12} \mathrm{M}$. A serial dilution of hemolymph was run in parallel to the native MIH (Fig. 8 insert). The detailed descriptions for antiserum production and RIA of $\mathrm{CHH}$ were previously provided [35]. The $\mathrm{ED}_{50}$ value of $\mathrm{CHH}$ was $4.00 \pm 0.02 \times$ $10^{-10} \mathrm{M}(\mathrm{N}=3)$. The RIA data were analyzed and plotted using the SOFTMax PRO v1.2.0 software (Molecular Devices).

\section{Ecdysteroid Radioimmunoassay}

Hemolymph samples $(10 \mu \mathrm{l})$ were analyzed for the total concentration of ecdysteroid using an Ecd-RIA with ecdysone specific antiserum and $\left[{ }^{3} \mathrm{H}\right]$ PoA (Perkin Elmer) and Ecd antiserum, as described [18]. Ecdysone served as a standard at concentrations ranging from $2.5 \mathrm{ng}$ to $30 \mathrm{pg} /$ tube. The results were analyzed using the AssayZap program (Biosoft) and the $\mathrm{EC}_{50}$ value of Ecd-RIA was $100 \pm$ $10 \mathrm{pg} /$ tube $(\mathrm{n}=10)$.

\section{Quantitative PCR (QPCR) analysis of VtG in the hepatopancreas and VtG ELISA}

Total RNA was extracted using the RNeasy mini kit (Qiagen). cDNA preparation and quantitative PCR (QPCR) analysis were conducted using the procedure described for the measurement of hepatopancreas $V t G \mathrm{mRNA}$ and with normalization against arginine kinase [3]. HnVtG RNA was measured by QPCR analysis using a pair of primers located in intron \#1 of the vitellogenin gene based on a 1539 bp partial sequence amplified from genomic DNA (GenBank accession number EU293808): $\quad$ Forward primer 5'GTTCCCTGCCTGGCTTCA3'; Reverse primer 5'CGGCTGTCGAGGTGATTATGA3'. This partial $V t G$ gene served as a template for the cRNA used in the standard curve. To avoid genomic DNA amplification, total RNA was treated with 1 unit/ $1 \mu \mathrm{g}$ RQ1 DNase (Promega) prior to reverse transcription, and the results obtained from cDNA amplification were corrected by subtracting the levels of non-reverse transcribed RNA amplification (no-RT control).

Vitellogenin levels in the incubation medium were determined by a competitive VtG ELISA. The media proteins were precipitated with $60 \%$ ammonium sulfate prior to the ELISA procedure as described [3]. When VtG levels were measured in the tissues and media, both were homogenized together in a "tissuelyser" (Qiagen) before ammonium sulphate precipitation.

\section{Incubation in vitro of hepatopancreas fragments with neuropeptides, actinomycin D or cycloheximide}

Hepatopancreas tissue was removed from vitellogenic females and washed in 10 volumes of ice-cold Medium199 medium (Sigma) (adjusted with $\mathrm{NaCl}$ to osmolarity of $960 \mathrm{mmol} / \mathrm{kg}$ ), with gentle agitation on ice for 2-3 h, and 3 medium exchanges. Hepatopancreas fragments ( 10 mg each) were directly weighed into $400 \mu \mathrm{l}$ medium containing $100 \mu \mathrm{g} / \mathrm{ml}$ BSA, $1 \times$ protease inhibitors cocktail for tissue culture (Sigma), and with or without the tested neuropeptide in 24 well plates (Corning). The plates were incubated at $23-24^{\circ} \mathrm{C}$ with gentle agitation for $6 \mathrm{~h}$. To test if other factors in the SG have roles in vitellogenesis, all HPLC fractions of SG extracts were pooled excluding crustacean hyperglycemic hormone precursor related peptide (CPRP), CHH, and MIH, and were also examined.

To further define the specific action of MIH, hepatopancreas fragments were exposed to actinomycin D (Sigma) or cycloheximide (Research Products international Corp.) at a final concentration of 0.5 and $10 \mu \mathrm{M}$ in the presence of $\mathrm{MIH}$. The actinomycin D results were compared to those of MIH treatment. The cycloheximide results were compared to those of $\mathrm{MIH}+0.1 \% \mathrm{v} / \mathrm{v}$ EtOH treatment, since EtOH was used as a vehicle for this reagent. In these experiments, VtG levels were measured in the medium and tissue and the results were obtained as $\mu \mathrm{g} / \mathrm{mg}$ total protein of both tissue 
and medium combined, before conversion into \% of control. For the measurement of $h n V t G$ RNA in the hepatopancreas, which indicates a de novo synthesis of newly transcribed and unprocessed mRNA, and reflects the actual transcription rates [46,47], incubation periods of 1 and $2 \mathrm{~h}$ were initially compared. Consequently, a $1 \mathrm{~h}$ incubation period was set for all experiments measuring $h n V t G$ RNA.

In general, control treatments were tested in sextuplicate and all other treatments in quadruplicates. At the end of the experiment, the tissue fragments were frozen at $-80^{\circ} \mathrm{C}$ until further analyses for $V t G$ mRNA and $h n V t G$ RNA QPCR, as described above. The results of several independent experiments were pooled, compared, and converted to \% of control due to high individual variations in VtG levels.

\section{Statistical analysis}

The data obtained from QPCR, RIA, and ELISA is presented as the mean \pm SEM. The results were subjected to GraphPad Instat 3 program (GraphPad Software). The data were analyzed using one-way ANOVA followed by Tukey-Kramer multiple comparison test. In all cases, a statistical difference was accepted at $\mathrm{P} \leq 0.05$.

\section{Abbreviations}

MIH: molt-inhibiting hormone; $\mathrm{CHH}$ : crustacean hyperglycemic hormone; QPCR: quantitative PCR; $V t G$ : vitellogenin mRNA; ELISA: enzyme linked immunosorbent assay; RIA: radioimmunoassay; VtG: vitellogenin protein.

\section{Competing interests}

The authors declare that they have no competing interests.

\section{Authors' contributions}

NZ carried out the concept, experimental design, and acquisition, analyses, and interpretation of data, and drafted and revised the manuscript including tables and figures. JMT participated in the discussions and revision of the manuscript. YZ involved in the acquisition of funding and contributed to discussions. JSC was involved in the acquisition of funding, contributed to the concept, experimental design, analyses, and interpretation of data, and revised the manuscript. All authors read and approved the final manuscript.

\section{Additional material}

\section{Additional file 1}

Ribosomal RNA stability during 6 incubation of hepatopancreas fragments. Gel electrophoresis of total RNA, extracted from hepatopancreas fragments before and after $6 \mathrm{~h}$ incubation, demonstrates that ribosomal RNA remains intact after $6 \mathrm{~h}$ incubation.

Click here for file

[http://www.biomedcentral.com/content/supplementary/17461448-5-7-S1.ppt]

\section{Acknowledgements}

This research was supported by the National Oceanic and Atmospheric Administration (NOAA), Chesapeake Bay Program Grant (NAI7FU284I) to the Blue Crab Advanced Research Consortium. We would like to thank Mr. J. Stubblefield for reading the manuscript and Professor E. Chang (Bodega Bay Marine Laboratory, University of California, Davis) for Ecdysone antiserum. This article is Center of Marine Biotechnology contribution \# $08-181$.

\section{References}

I. Aiken DE, Waddy SL: Reproductive biology. In The Biology and Management of Lobsters: Physiology and Behavior Volume I. Edited by: Cobb JS, Philips BF. New York: Academic Press; 1980:215-276.

2. Adiyodi RG, Subramoniam T: Oogenesis, oviposition and oosorption. In Reproductive Biology of Invertebrates Volume I. Edited by: Adiyodi KG, Adiyodi RG. New York: John Wiley \& Sons Ltd; 1983:443-495.

3. Zmora N, Trant MJ, Chan SM, Chung JS: Vitellogenin and its messenger RNA during ovarian development in the female blue crab, Callinectes sapidus: Gene expression, synthesis, transport, and cleavage. Biol Reprod 2007, 77:138-146.

4. Passano LM: Molting and its control. In The Physiology of Crustacea Volume I. Edited by: Waterman TH. New York: Academic Press, Inc; 1960:473-536.

5. Hinsch GW: Some factors controlling reproduction in the spider crab, Libinia emarginata. Biol Bull 1972, 143:358-366.

6. Donaldson WE, Cooney RJ, Hilsinger JR: Growth, age and size at maturity of Tanner crab, Chionectes bairdi M.J. Rathbun, in the northern gulf of Alaska (Decapoda, Brachyura). Crustacea 1981, 40:286-301.

7. Skinner DM: Molting and regeneration. In The Biology of Crustacea Edited by: Bliss DE, Mantel LH. New York: Academic Press; 1985:43-146.

8. Carlisle DB, Knowels FG: Endocrine Control in Crustaceans London and New York: University Press; 1959.

9. Havens KJ, McConaugha JR: Molting in the mature female blue crab, Callinectes sapidus Rathbun. Bull Mar Sci 1990, 46(I):37-47.

10. Van Herp F, Soyez D: Arthropoda - crustacea. In Reproductive Biology of Invertebrates: Progress in Reproductive Endocrinology Volume 8. Edited by: Adiyodi KG, Adiyodi RG, Adams TS. John Wiley \& sons; 1977:247-275.

II. Fingerman M: Crustacean endocrinology: a retrospective, prospective, and introspective analysis. Physiol Zool 1997, 70(3):257-269.

12. Wainwright G, Webster SG, Wilkinson MC, Chung JS, Rees $\mathrm{HH}$ Structure and significance of mandibular organ-inhibiting hormone in the crab, Cancer pagurus. Involvement in multihormonal regulation of growth and reproduction. J Biol Chem 1996, 27 I(22): | 2749-12754.

13. De Kleijn DPV, Van Herp F: Molecular biology of neurohormone precursors in the eyestalk of crustacea. Comp Biochem Physiol B, Biochem Mol Biol 1995, I I 2:573-579.

14. Keller R: Crustacean neuropeptides: structure, functions and comparative aspects. Experientia 1992, 48:439-448.

15. Chan SM, Gu PL, Chu KH, Tobe SS: Crustacean neuropeptide genes of the CHH/MIH/GIH family: implications from molecular studies. Gen Comp Endocrinol 2003, 134:214-219.

16. Webster SG: High-affinity binding of putative moult-inhibiting hormone (MIH) and crustacean hyperglycemic hormone (CHH) to membrane bound receptors on the $Y$ - organ of the shore crab Carcinus maenas. Proc R Soc Lond, B, Biol Sci 1993, B 25I:53-59.

17. Webster SG: Amino acid sequence of putative moult-inhibiting hormone from the crab Carcinus maenas. Proc Biol Sci. I99|, 244(I3 I I):247-252.

18. Chung JS, Webster SG: Does $\mathbf{N}$-terminal pyroglutamate residue have any physiological significance for crab hyperglycemic neuropeptides? Eur J Biochem 1996, 240:358-364.

19. Webster S, Keller R: Physiology and biochemistry of crustacean neurohormonal peptides. In Peptides and amines in invertebrates Edited by: Thorndyke M, Goldsworthy G. Cambridge Cambridge University Press; 1987.

20. Böcking D, Dircksen $H$, Keller R: The crustacean neuropeptides of the CHH/MIH/GIH family: structures and biological activ- 
ities. In The Crustacean Nervous System Edited by: Wiese K. Berlin: Springer-Verlag; 2002:84-97.

21. Mattson MP, Spaziani E: Regulation of Y-organ ecdysteroidogenesis by molt-inhibiting hormone in crabs: involvement of cyclic AMP-mediated protein synthesis. Gen Comp Endocrinol 1986, 63:4|4-423.

22. Imayavaramban L, Dhayaparan D, Devaraj H: Molecular mechanism of molt-inhibiting hormone (MIH) induced suppression of ecdysteroidogenesis in the Y-organ of mud crab: Scylla serrata. FEBS Lett 2007, 58I(27):5167-5172.

23. Watson RD, Spaziani E, Bollenbacher WE: Regulation of ecdysone biosynthesis in insects and crustaceans: a comparison. In Ecdysone Edited by: Koolman J. New York: Thieme Medical Publisher; 1989:188-203.

24. Chang ES, O'Connor JD: Crustacea: molting. In Endocrinology of Selected Invertebrate Types Edited by: Laufer L, Downer RGH. New York: Liss, AR; 1988:259-278.

25. Webster SG: Neuropeptides inhibiting growth and reproduction in crustaceans. In Recent Advances in Arthropod Endocrinology Edited by: Coast GM, Webster SG. Cambridge: Cambridge University Press; 1998:33-52.

26. Chaves AR: Effect of $\mathbf{X}$-organ sinus gland extract on [(35)S] methionine incorporation to the ovary of the red swamp crawfish Procambarus clarkii. Comp Biochem Physiol, Part A Mol Integr Physiol 2000, I 26:407-4I 3.

27. Bomirski A, Klek-Kawi'nska E: Ovary-inhibiting hormone activity in shrimp (Crangon crangon) eyestalks during the annual reproductive cycle. Gen Comp Endocrinol 1975, 25(I):9-13.

28. Ohira T, Okumura T, Suzuki M, Yajima $Y$, Tsutsui N, Wilder $M$ Nagasawa H: Production and characterization of recombinant vitellogenesis-inhibiting hormone from the American lobster Homarus americanus. Peptides 2006, 27: $125 \mid-1258$.

29. Edomi P, Azzoni E, Mettulio R, Pandolfelli N, Ferrero AE, Giulianini P: Gonad-inhibiting hormone of the Norway lobster (Nephrops norvegicus). Gene 2002, 284:93-102.

30. De Klein DP, Sleutels FJ, Martenz GJ, Van Herp F: Cloning and expression of mRNA encoding prepro-gonad-inhibiting hormone (GIH) in the lobster Homarus americanus. FEBS lett I994, 353:255-258.

31. Ollivaux C, Vinh J, Soyez D, Toullec JY: Crustacean hyperglycemic and vitellogenesis-inhibiting hormones in the lobster Homarus gammarus. FEBS / 2006, 273(I0):215I-2160.

32. Tsutsui N, Ohira T, Kawazoe I, Takahashi A, Wilder MN: Purification of sinus gland peptides having vitellogenesis-inhibiting activity from the white leg shrimp Litopenaeus vannamei. Ma Biotech 2007, 9:360-369.

33. Greve P, Sorokine O, Berges T, Lacombe C, Van Dorsselaer A, Martin G: Isolation and amino acid sequence of a peptide with vitellogenesis inhibiting activity from the terrestrial isopod Armadillidium vulgare (Crustacea). Gen Comp Endocrinol 1999, I | 5:406-4|4.

34. Tiu SH, Chan SM: The use of recombinant protein and RNA interference approaches to study the reproductive functions of a gonad-stimulating hormone from the shrimp Metapenaeus ensis. FEBS / 2007, 274(I7):4385-4395.

35. Chung $\mathrm{S}$, Zmora N: Functional studies of crustacean hyperglycaemic hormones (CHHs) of the blue crab, Callinectes sapidus: the expression and release of $\mathrm{CHH}$ in eyestalk and pericardial organ in response to environmental stress. FEBS j2008, 275(4):693-704.

36. Lee KJ, Watson DR, Roer RD: Molt-inhibiting hormone mRNA levels and ecdysteroid titer during a molt cycle of the blue crab, Callinectes sapidus. Biochem Biophys Res Commun 1998, 249:624-627.

37. Fingerman M: Roles of neurotransmitters in regulating reproductive hormone release and gonadal maturation in decapod crustaceans. Invertebr Reprod Dev 1997, 31:47-54.

38. Panouse JB: Influence de I'ablation du pedoncule oculaire sur la croissance de l'ovaire chez la crevette leander serratus. C R Acad Sci III, Sci Vie 1943, 2I 7:553-555.

39. Zmora N, Sagi A, Zohar Y, Chung J: Molt-inhibiting hormone stimulates vitellogenesis at advanced ovarian developmental stages in the female blue crab, Callinectes sapidus 2: novel specific binding sites in hepatopancreas and CAMP as a second messenger. Saline Systems. 2009, 5(I):6.
40. Khayat M, Yang W], Aida K, Nagasawa H, Tietz A, Funkenstein B, Lubzens $E$ : Hyperglycaemic hormones inhibit protein and mRNA synthesis in in vitro - incubated ovarian fragments of the marine shrimp Penaeus semisulcatus. Gen Comp Endocrinol 1998, II 0:307-318.

4I. Tsutsui N, Katayama H, Ohira T, Nagasawa H, Wilder MN, Aida K: The effects of crustacean hyperglycemic hormone-family peptides on vitellogenin gene expression in the kuruma prawn, Marsupenaeus japonicus. Gen Comp Endocrinol 2005, 144(3):232-239.

42. Tamone S, Adams M, Dutton J: Effect of eyestalk-ablation on circulating ecdysteroids in hemolymph of snow crab, Chionoecetes opilio: Physiological evidence for a terminal molt. Integr Comp Biol 2005, 45: I66-I77.

43. Lee RF, Puppione DL: Lipoproteins I and II from the hemolymph of the blue crab Callinectes sapidus: lipoprotein II associated with vitellogenesis. J Exp Zool 1988, 248:278-289.

44. Chung JS, Webster SG: Moult cycle-related changes in biological activity of moult-inhibiting hormone $(\mathrm{MIH})$ and crustacean hyperglycaemic hormone $(\mathrm{CHH})$ in the crab Carcinus maenas. Eur J Biochem 2003, 270:3280-3288.

45. Chung JS, Webster SG: Dynamics of in vitro release of moltinhibiting hormone and crustacean hyperglycemic hormone in the shore crab, Carcinus maenas. Endocrinology 2005, I46:5545-555 I.

46. Sugimoto K, Mori K, Uchida K, Kobayashi D, Itoi K: Quantitative analysis of thyroid-stimulating hormone messenger RNA and heterogeneous nuclear RNA in hypothyroid rats. Brain Res Bull 2007, 74: |42-| 46.

47. Jensen L, Whitehead AS: Competitive reverse transcription polymerase chain reaction for quantifying pre-mRNA and mRNA of major acute phase proteins. J Immunol Methods 1998, 215(I-2):45-58.

Publish with Biomed Central and every scientist can read your work free of charge

"BioMed Central will be the most significant development for disseminating the results of biomedical research in our lifetime. "

Sir Paul Nurse, Cancer Research UK

Your research papers will be:

- available free of charge to the entire biomedical community

- peer reviewed and published immediately upon acceptance

- cited in PubMed and archived on PubMed Central

- yours - you keep the copyright 